\section{SCIENCE IN PEACE AND WAR*}

BY WATSON DAVIS

Director of Science Service, Washington, D.C.

$I^{\mathrm{N}}$ N every sense this is a scientific war. On the fighting fronts, precisely built machines of defence destruction are manned by men expertly trained and laboriously supplied. On the home fronts production, transport and world economic strategy are the prime concern. Backing up this gigantic war effort are knowledge, thought, planning and research. Of particular importance is the scientific research, not just of to-day but of past years.

Unfortunately, the layman is usually oblivious to the scientific basis of our civilization until something goes wrong. To people without the vision and power that experiment and interpretation of experiment bring, the universe is a static, unchanging, finished creation which, nevertheless, rushes on and leaves them hopelessly behind. That is what has happened and will happen to individuals or nations without the precious ferment of scientific research. All tradition, lore, or musty mores are hopeless before the onslaught of new ideas, whether those ideas project a panzer attack or give a new mode of peaceful living to the world.

The scientific method in one sense is completely divorced from social consequences. Men of bad will can, with unenviable cunning, use the priceless, timetested, experimental method to fashion offensive weapons which can be used to annihilate the environment and the people from whom true science must bring the continuing progress of the world. The metallurgist who makes possible a fine, keen butcher knife of stainless steel, a useful product of his technology, can of himself do little to prevent the use of that knife for murder by a mad butcher.

In another sense, the utilization of the resources of the world, including the knowledge and methods and mechanisms produced by science, is a real concern to those who are scientifically creative. It would be logical and not too much to expect that men of science take more than a democratically average interest in preventing destruction and aggression, misappropriation of our material resources, the distribution of good things of this earth among all the peoples, and the assurance of that essential minimum of food, clothing, shelter, education and freedom to all. This means that men of science and engineers must be more than creative specialists; they must be leaders in living and social organization, within the limits of their abilities.

Science can greet with equanimity the unreasoned criticisms that sometimes come to it, stating that science has created new and more deadly weapons. Of course it has. It has created mechanisms and devices for offence, as well as defence, just as it has brought into being many new homely, peaceful things of life. From the earliest days of war, even before lance, sword, and bow-and-arrow gave way to the chemistry of gunpowder, the major developments of war were the creation of science. Smokeless powder, the rifle, artillery, the submarine, high explosives, the aeroplane, armour, poison gas : all of these are from science's armoury.

There should be no undue surprise if and when novel and unconventional weapons come to light in this War. Added to the devices of previous conflicts,

* Based on an address delivered beforc the Institute of Public Affairs, University of Virginia, on July 7 . we have in this great world-enveloping struggle, weapons and devices new either in themselves or in their application. First among these perhaps is the aeroplane, with its revolution of strategy and tactics. We see in the modern war plane the result of aerodynamical research and developments in metallurgy and petroleum chemistry.

We know that there are radio devices which reach many miles out to sea to detect aeroplanes and ships, devices which may very well usher in a new era of radio application once peace releases them from their essential war work. We know that rockets in various forms are finding fighting applications, and we can guess that there is much more experimentation to be done.

There are new defensive weapons extensively used for the first time in this War about which we may talk freely; such weapons as those used in medicine : vaccines against diseases that hitherto were uncontrollable, the array of sulpha drugs effective against some of the great killers of war and peace, and improved methods of sanitation and prevention which, although unspectacular, serve an essential role. It is altogether possible that this will be the first war in which wounds born of battle will take a larger percentage of human toll than disease and pestilence. If we do escape a great plague, it will be a triumph for our fighters against disease-with considerable credit to the omnipresent factor of fate.

On the production front one of the great problems has been the supply of raw materials. Scientific workers and engineers, as well as industrialists, have had to do some violent readjusting of viewpoints in worrying about supplies. In the transition from an economy of plenty and oversupply to a regime of scarcity and priorities, there has been ample oppor. tunity for high ingenuity and for realization upon many seemingly wild goose chases of the ressarch laboratories.

Almost every day we hear of some new achieve. ment in producing a new material for an old use or a new use for an old material. There is a new kind of glass that replaces cork as the buoyant material in life preservers-glass that is puffed up like bread dough and looks like a cinder block. Noble silver goes to work and carries electricity more efficiently than copper and is substituted for tin in solder. The normal array of alloy steels is simplified to meet the emergency situation and scarce alloying ingredients are conserved.

There is in process a revolution in food preservation that may well rival the introduction of canning that came of the Napoleonic wars. This grows out of the shortage in shipping space for overseas ship. ments, the lack of tin for food cans, and the rise of the quick freezing processes. Dehydration of foods of all sorts-meats, vegetables, milk-is rapidly becoming a widespread standard practice that will undoubtedly persist after the War. Plastic coatings serve in place of tin on food cans. Glass jars come into wider use.

These are random samples of some of the things that are happening in industry under the influence of the War. Some such things are born of the necessity and impetus of the War, but it should be kept in mind that war itself is a waster and despoiler in science and engineering as in almost all other things. Under the white-hot urgency of physical struggle certain developments are accelerated, but the creative beginnings usually will be found to date back to the more reasoned days of peace. 
To advise is about as far as men of science and engineers can go in actually fighting the War with their new weapons. The Fighting Services must use tools furnished them. Men of science can advise with some vigour and emphasis. Secrecy is necessary, of course, to keep the enemy from knowing what is being done. But secrecy can hide inaction as well as surprising, aggressive preparation. As with production and military action, the great problem is getting there first with the most and newest, and of meeting any new scientific weapon that the enemy might spring on us with an antidote within the minimum of time. The classic example of applying the antidote in this War was the neutralizing of the magnetic mines of the Germans by the degaussing belts for ships developed in Great Britain.

The 'mental front' ranks in importance with the fighting fronts in this War. It is neglected or handled piecemeal by this and that agency because it is shapeless, permeating battle lines that exist everywhere - in the United Nations and in the occupied and enemy countries. This mental front is within each of us. It is called morale or propaganda or the war of nerves. It is full of complexities and intangibles. It provides at once the greatest drive toward victory and the speediest retreat toward subjection. It is what makes the Russians-women and children as well as men-fight in the streets and scorch the earth. It is what immobilizes and makes uninterested noncombatants out of the peoples of some countries when invaders are at their front doors. The mental front is concerned with human motivation and mass emotions. It is the great neglected area in the War because it is not made of steel or tramping men.

Because of the nature of what they work with, psychologists and psychiatrists have great difficulty in forming and maintaining the lines along which they fight effectively. In part not enough is known about why human beings do things or do not do things, why they are willing to die or why they want to run away, either in ordinary life or in war. Much more is known than is being used, although more psychologists are used in this war effort than in any other. Experts in diplomacy, economic warfare and public opinion work as artists rather than scientists. Joint efforts by artists and scientists are sometimes difficult to arrange, but when accomplished often bring worthwhile results.

As science fights the war, it is also fighting for the peace to come. If this is not the case, the peace to come will be but an armistice breeding new wars. The design of the world organization to come must be on our drawing boards as our troops fight if we are to reconstruct the world in the shape we wish. More than swift, time-annihilating aeroplanes will be necessary to bind the world together in a new democratic order.

Many of the things happening in these crowded crucial months are winning the peace at home and conducting 'the people's revolution' as Mr. Henry Wallace, vice-president of the United States, has called it. To build a just, charitable and enduring peace, he has said, inspires production to the limit, transportation as rapidly as possible to the field of battle, and fighting "with all that is in us". In fighting the War, science paves the way for peace that must come. As we fight for a sane and livable world, we can be inspired by Mr. Wallace's declaration : "Modern science, when devoted wholeheartedly to the general welfare, has in it potentialities of which we do not yet dream."

\section{THE IMPACT OF SCIENCE ON AGRICULTURE}

\author{
BY SIR JOHN RUSSELL, F.R.S.
}

$\mathrm{I}^{\mathrm{N}}$ spite of considerable diversity, agricultural systems in the pre-scientific days usually possessed two features in common: they aimed first and foremost at providing complete subsistence for the community, money crops being a subordinate considera. tion; and they included measures for conserving the productiveness of the land, either by the so-called fallowing, or by letting the land revert to the wild state, or by some other device. Although these systems had a low level of productiveness they provided food for indefinitely long periods of time, and in addition possessed certain social advantages. In the system followed in Great Britain, around the Baltic, in Northern India and elsewhere, the land was divided into strips which were shared out among the participants for the purposes of ensuring equitable distribution of good and bad land. The whole complex of peasant life developed some creative art which showed itself in a love of colour, folk music and dancing, embroidery, wood carving, pottery, iron work and other peasant arts and crafts.

Unfortunately, the strip system of farming was incapable of improvement by scientific means, and as soon as the peasants insisted on a higher standard of living it had to go. The method of change varied in different countries: Russia adopted one way and Poland another. Instead of scattered strips the agricultural holding was brought into one self-contained unit. Here science was able to play its part. Unfortunately, as science came in so the peasants' arts and crafts, the colour, the singing and the dancing got somehow erowded out; they ceased to be spontaneous peasant activities and are becoming only museum pieces. It would be a great advantage to the countryside if, somehow, this apparent antagonism could be overcome.

In Great Britain the change to unified holdings had been made before the scientific era and so we were able at once to introduce science into our agriculture. It led to great improvements and in the 1860 's and 1870's our farming superiority was widely admitted. Then came a remarkable sequence of events illustrating the difficulty of anything less than 'total' application of science to agriculture. The prairies of North America were gradually being opened up for settlement. The development of implement design made cereal cultivation possible, while plant selection and breeding - then only in their early stagesprovided suitable varieties. Transport and business' agencies arranged to take and pay for the produce. A very cheap agricultural system was worked out, and the operations were on so large a scale that considerable economies were possible with the result that wheat was put on British markets at prices below those at which our farmers could grow it. Similar developments occurred in the production of butter, cheese and meat, mitigated somewhat in the latter case by the fact that British produce always had a superior quality and so had some preference in the market. Our farmers could not compete, and British agriculture fell in the 1890's to a very low level. Then a more comprehensive application of science was attempted which was gradually directed to an increase in the output per man-hour, so allowing a higher rate of wage sufficient to keep some of the men on 